DOI: $10.4274 /$ tpa.46.80

\title{
Çocuk acil servisine başuuran zehirlenme olgularının geriye dönük olarak değerlendirilmesi
} Evaluation of the poisoning cases who applied to the
pediatrics emergency unit

Veysel Sümer, Ekrem Güler, Ramazan Karanfil ${ }^{\star}$, Tahir Dalkiran, Halil Gürsoy, Mesut Garipardlç, Mehmet Davutoğlu Kahramanmaraş Sütçü Imam Üniversitesi, Tıp Fakültesi Çocuk Sağlığı ve Hastalıkları Anabilim Dalı, Kahramanmaraş, Türkiye

* Kahramanmaraş Sütçü Imam Üniversitesi, Tıp Fakültesi Adli Tıp Anabilim Dalı, Kahramanmaraş, Türkiye

Özet

Amaç: Çocukluk çağı zehirlenmeleri ülkemizde sık görülen bir sağlık sorunudur. Bu çalışmada bölgemizde görülen çocukluk çağı zehirlenmelerinin epidemiyolojik ve klinik özelliklerin belirlenmesi ve gerekli önlemler için yol göstermesi amaçlanmıştır.

Gereç ve Yöntem: Bu çalışmada Kahramanmaraş Sütçü İmam Üniversitesi Tıp Fakültesi Çocuk Acil Servisi'ne 2003-2009 tarihleri arasında zehirlenme nedeniyle getirilen 233 olgunun epidemiyolojik özellikleri geriye dönük olarak Statistical Package for the Social Sciences (SPSS) 16.0 (IBM Company Chicago, Illinois) istatistik programıyla değerlendirildi.

Bulgular: Zehirlenme olgularının tüm acil başvurularına oranı \%1,14, \%60,5'i erkek, \%39,5 i kız ve erkek/kız oranı ise 1,5/1'di. Zehirlenmelerin en sık görüldüğü yaş 7 ay-4 yaş $(\% 73,8)$ grubuydu. Zehirlenme etkeni olan maddeler en sık sindirim sistemi yoluyla (\%91) ve bunlarında çoğu kaza sonucu $(\% 97)$ alınmıştı. Zehirlenmeye neden olan en sık etken $(\% 54,9)$ farmakolojik olmayan ajanlardı. Bunlar sıklık sırasına göre yakıcı-koroziv maddeler $(\% 25,3)$, insektisit ve pestisitler $(\% 7,3)$, karbonmonoksit $(\% 6)$, hidrokarbonlar $(\% 5,2)$, fare zehiri $(\% 2,6)$, mantarlar $(\% 2,6)$ ve bitkisel ürünlerdi $(\% 2,6)$. Zehirlenmeye neden olan farmakolojik ajanlar ise ikinci en sık $(\% 41,2)$ etkendi. Bunlar sırasıyla; antidepresanlar (\%15,5), demir içeren ilaçlar (\%3), antipsikotikler $(\% 2,6)$ antikolinerjikler $(\% 1,7)$, parasetamol $(\% 1,7)$, kardiyovasküler sistem ilaçları $(\% 1,7)$, sindirim sistemi ilaçlarıydı (\%1,7).

Çıkarımlar: Bölgemizdeki çocukluk çağı zehirlenmelerinde ilk sırada ilaçlar, ikinci sırada ise yakıcı-koroziv maddeler yer almaktadır. (Türk Ped Arş 2011; 46: 234-40)

Anahtar sözcükler: Çocukluk çağı, epidemiyoloji, Kahramanmaraş, zehirlenme

\section{Summary}

Aim: Childhood poisoning is a frequently seen health problem in our country. In this study; determination of epidemiological and clinical features of childhood poisoning in our region and for the necessary measures aimed inferences.

Material and Method: In this study; epidemiologic features of 233 cases who applied to the Pediatrics Emergency Unit of Kahramanmaras Sütcü Imam University Faculty of Medicine between the years 2003-2009 were evaluated with Statistical Package for the Social Sciences (SPSS) 16.0 (IBM Company Chicago, Illinois) statistic program retrospectively.

Results: The ratio of poisoning cases to all pediatric emergency admissions was $1.14 \%$. The gender distribution was $60.5 \%$ male and $39.5 \%$ female and the ratio of male/female 1.5/1. The highest proportion of poisoning was in the 7 months-4 years of age group (73.8\%). Most commonly poisoning agents had been received by of the gastrointestinal route (91\%) and accidentaly (97\%). The most common factor leading to intoxication was non-pharmacological agents (54.9\%). These were in order of frequency caustic-corrosive substances (25.3\%), insecticides and pesticides $(7.3 \%)$, carbon monoxide $(6 \%)$, hydrocarbons $(5.2 \%)$, rat poison $(2.6 \%)$, fungi $(2.6 \%)$, and herbal products $(2.6 \%)$. Pharmacological agents that caused intoxication were the second most common (41.2\%) factor. These were, respectively, antidepressants (15.5\%), iron-containing medications (3\%), antipsychotics (2.6\%), anticholinergics (1.7\%), paracetamol (1.7\%), cardiovascular system drugs (1.7\%), and gastrointestinal drugs (1.7\%).

Conclusions: In our region the most common poisoning agents were drugs followed by caustic-corrosive substances. (Turk Arch Ped 2011; 46: 234-40)

Key words: Childhood, etiology, Kahramanmaras, poisoning

Yazışma Adresi/Address for Correspondence: Dr. Ekrem Güler, Kahramanmaraş Sütçü İmam Üniversitesi Tıp Fakültesi, Çocuk Sağlığı ve Hastalıkları Anabilim Dalı, Kahramanmaraş, Türkiye E-posta: ekremguler@hotmail.com Geliş Tarihi/Received: 05.10.2010 Kabul Tarihi/Accepted: 06.04.2011

Türk Pediatri Arşivi Dergisi, Galenos Yayınevi tarafindan basılmıştır. / Turkish Archives of Pediatrics, published by Galenos Publishing 


\section{Giriş}

Türkiye gibi gelişmekte olan ülkelerde zehirlenmeler ve buna bağlı ölüm oranlarının yüksek olması, çocukluk çağı zehirlenmelerini, çözümlenmesi gereken önemli bir sorun durumuna getirmiştir (1-6).

Zehirlenmeler her yaş grubunda görülmekle birlikte, çocukluk yaş grubunda daha sıktır ve daha ölümcül seyretmektedir. 1997 yılında Türkiye'nin her bölgesinden 38 sağlık kuruluşunun verilerine dayanılarak yapılan bir araştırmada 5077 çocuk zehirlenme olgusu değerlendirilmiş ve toplam acil olgular içindeki oranının \%0,9 olduğu saptanmıştır (2).

Sayısı ve önemi giderek artan çocukluk çağı kazaları teknolojinin hızla ilerlemesi, bilinçli beslenme, koruyucu hekimlik uygulamalarının giderek yaygınlaşması ve enfeksiyon hastaIıklarının tedavi edilebilir olması nedeni ile çocuk ölüm sebepleri arasında öne çıkmaktadır. Ülkemizde çocuklarda zehirlenmeler trafik kazası, düșme ve yanıklardan sonra dördüncü sıklıkta görülen kaza çeşididir (3). Ülkemizde yapılan çalışmalarda çocuklarda zehirlenmelere bağlı ölüm oranının \%05,5 arasında değiştiği görülmüştür $(4,5)$.

Zehirlenmeye yol açan etkenler ülkeden ülkeye, aynı ülkede bölgeden bölgeye, aynı bölgede yıllar içinde değişebilmektedir. Aynı şekilde zehirlenme etkenleri yaşa, cinsiyete, ailenin eğitim düzeyine, yaşanılan bölgenin gelenek ve göreneklerine ve mevsimlere göre değişmektedir. Bu nedenle, her ülkenin kendi zehirlenme profilini belirlemesi, buna göre karşı karşıya kaldığı risk ve tehditlere göre gerekli önlemleri alması gerekmektedir (6).

Bu çalışmada bölgemizde görülen çocukluk çağı zehirlenmelerinin epidemiyolojik ve klinik özelliklerin belirlenmesi ve gerekli önlemler için yol göstermesi amaçlanmıştır.

\section{Gereç ve Yöntem}

Kahramanmaraş, Sütçü İmam Üniversitesi Tıp Fakültesi Çocuk Acil Polikliniği'ne Eylül 2003 ile Ağustos 2009 tarihleri arasında akut zehirlenme nedeni ile başvuran olguların dosyaları geriye dönük olarak incelendi. Gıda zehirlenmesi ve hayvan/böcek ısırık olguları çalışmaya dahil edilmedi.

Olgular; 7 ay-4 yaş, 5-8 yaș, 9-12 yaş ve 13-17 yaş olmak üzere toplam dört gruba ayrılarak incelendi. Ancak ilk beş yaşta yoğunluk olması nedeniyle ilk altı yaşı daha ayrıntılı görme amaçıı tüm olguların yaşlara dağılımı değerlendirilirken ayrıcalıklı davranıldı; 1, 2, 3, 4, 5, 6, 7-11 ve 12-17 yaş olarak gruplandırıldı.

Başvuru tarihi bakımından olgu sayıları mevsimlere, aylara, zehirlenme ve başvuru saatine göre ise iki saatlik zaman dilimlerine ayrılarak kaydedildi ve incelendi. Getirildiği yerleşim birimi bakımından il merkezi, ilçeler ve komşu iller şeklinde gruplandırıldı.

Zehirlenme etkenleri yönünden farmakolojik ajanlar, farmakolojik olmayan ajanlar ve etkeni bilinmeyen zehirlenmeler olarak üç guruba ayrıldı. Farmakolojik ajanlar 22 alt gruba ve farmakolojik olmayan ajanlar 11 alt gruba ayrıldı. Yaş gruplarI ve mevsimlere göre zehirlenme etkenleri incelenirken farmakolojik ajanlar tek başına bir grup, farmakolojik olmayan ajanlar ise etkenlerine göre gruplandırıldı.
Zehirlenmenin meydana geliș șekli bakımından kaza, intihar ve iyatrojenik olmak üzere üç guruba ayrılarak incelendi. Toksik maddenin alınış yolu bakımından ağız, solunum, cilt yoluyla ve göze temas yoluyla zehirlenme olarak gruplandırıldı.

Olgular ayrıca zehirlenme ile hastaneye başvuru arasındaki süre, zehirlenmenin yol açtığı belirti ve bulgular, hastanemize başvurmadan önce bir sağlık kuruluşuna başvurusu ve uygulanan tedaviler, çocuk acil servisimizde uygulanan tedavi ve takip süresi ve çocuk acil servis sonrası taburcu, yatış, sevk yönünden, yatış yapılanlara serviste uygulanan tedavi yöntemleri, hastanedeki izlem süreleri ve tedavinin sonuçları yönünden değerlendirildi.

Veriler Statistical Package for the Social Sciences (SPSS) 16.0 (IBM Company Chicago, Illinois) istatistik programılla değerlendirildi.

\section{Bulgular}

Çocuk Acil Polikliniğimize Eylül 2003-Ağustos 2009 tarihleri arasında getirilen 20278 hastanın, 233'ünün $(\% 1,14)$ akut zehirlenme tanısı aldığı tespit edildi. Yaşları 7 ay-17 yaş (ortalama 4,3 $\pm 3,5$ yıl) arasında değişen olguların cinsiyet dağılımına bakıldığında; 141'i $(\% 60,5)$ erkek, 92'si $(\% 39,5)$ kız idi. Zehirlenmelerin 7 ay-4 yaş, 5-8 yaş, 9-12 yaş gruplarında sırasıyla \%61,6, \%69,0, \%54,5 erkeklerde, 13-17 yaş grubunda ise $\% 70$ kızlarda daha sık olduğu görüldü.

Zehirlenmeler en sık 7 ay-4 yaş grubunda $(\% 73,8)$ ve bu yaş grubu içinde de en sık $(\% 26,6)$ iki yaşındaki çocuklarda idi (Şekil 1).

Olguların geldikleri yerler; 167'si $(\% 71,7)$ il merkezinden, geriye kalan 64'ü $(\% 27,5)$ ilçelerinden ve ikisi $(\% 0,8)$ ise çevre illerdendi.

Zehirlenme etkeni olan maddelerin alınış yolları sıklık sırasına göre; 212'sinde sindirim yoluyla (\%91), 14'ünde solunum yoluyla (\%6), üçünde sindirim yolu, solunum yolu ve deriden birlikte $(\% 1,3)$, ikisinde deri yoluyla $(\% 0,9)$, birinde kas içine enjeksiyon $(\% 0,4)$ ve birinde de bilinmeyen bir yol ile $(\% 0,4)$ idi.

Zehirlenmelerin 226'sı (\%97) kaza sonucu, beşi $(\% 2,1)$ intihar amacıyla, ikisi $(\% 0,9)$ ise iyatrojenik olarak meydana gelmişti. İntihar amaçlı olan beş zehirlenmenin tümü 13-17 yaş grubunda ve tamamı kız idi.

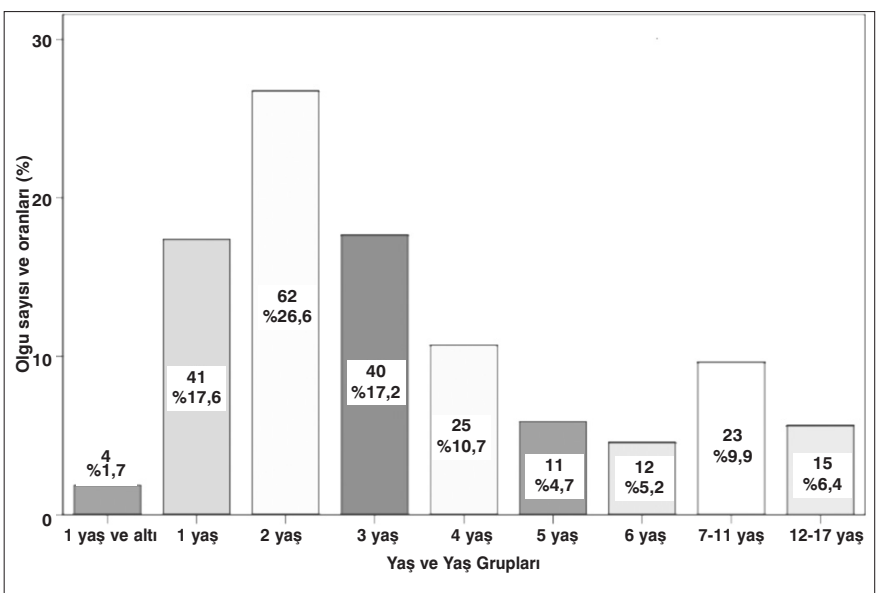

Şekil 1: Zehirlenme olgularının yaş gruplarına göre dağııımı 
Tablo 1. Zehirlenme olgularının yaş grupları ve cinsiyete göre dağılımı

\begin{tabular}{|c|c|c|c|c|c|c|}
\hline \multirow{2}{*}{ Yaş Grupları } & \multicolumn{4}{|c|}{ Cinsiyet } & & \\
\hline & $\mathbf{n}$ & $\% *$ & $\mathbf{n}$ & $\%$ & $\mathbf{n}$ & $\% * *$ \\
\hline 7 ay-4 yaş & 66 & $\% 38,4$ & 106 & $\% 61,6$ & 172 & $\% 73,8$ \\
\hline 5-8 yaş & 9 & $\% 31,0$ & 20 & $\% 69,0$ & 29 & $\% 12,4$ \\
\hline $13-17$ yaş & 7 & $\% 70,0$ & 3 & $\% 30,0$ & 10 & $\% 4,3$ \\
\hline Toplam & 92 & $\% 39,5$ & 141 & $\% 60,5$ & 233 & $\% 100$ \\
\hline
\end{tabular}

*: Aynı yaş gurubundaki olguların kız/erkek oranları,

**: Toplam zehirlenme olgularının yaş gruplarına dağılım oranları

Zehirlenmelerin mevsimlere göre dağılımı incelendiğinde; 84 'ü $(\% 36,1)$ yaz ve 76 'sı $(\% 32,6)$ ilkbahar, 40'ı $(\% 17,2)$ sonbahar, 33'ü $(\% 14,2)$ ise kış aylarında meydana gelmişti. Aylara göre dağılımı incelendiğinde; en çok olgunun olduğu ay Temmuz (\%15) daha sonra sırayla Ağustos, Mart ve Nisan idi.

Zehirlenmeler en sık 16:00-18:00 saatleri arasında $(\% 16,3)$ ve diğer sık zehirlenmeler ise gündüz saatleri olan 08:00-10:00, 12:00-14:00, 14:00-16:00 saatlerindeydi.

Zehirlenme ile hastaneye başvuru arasında geçen süre 15 dakika ile 72 saat arasında (3,98 $\pm 2,0$ saat) değişmekteydi. Yarısının $(\% 50,2)$ ilk bir saat, $\% 71$ 'inin dördüncü saat, $\% 88,8$ 'inin ilk sekiz saat içinde hastanemize başvurdukları saptandı.

Acil polikliniğimize en sık başvuru saatleri 18:00-22:00 arasındaydı.

Olguların 96'sında $(\% 41,2)$ farmakolojik, 128 'inde $(\% 54,9)$ farmakolojik olmayan bir madde zehirlenme etkeni olup, dokuzunda $(\% 3,9)$ zehirlenme etkeni saptanamadı. Olguların 11 'inde $(\% 4,7)$ iki veya daha fazla ilacın birden alındığı öğrenildi. Zehirlenmeye neden olan ajanlar incelendiğinde en sık etkenin farmakolojik olmayan ajanlar olduğu $(\% 54,9)$ görüldü. Zehirlenmeye neden olan farmakolojik olmayan ajanlardan yakıcı-korozif maddeler $(\% 25,3)$ ilk sırada ve insektisit ve pestisitler $(\% 7,3)$ ise ikinci sırada idi (Tablo 1).

Zehirlenmeye en sık neden olan ilaç grupları sırasıyla; antidepresanlar (\%15,5), demir içeren ilaçlar (\%3), antipsikotikler $(\% 2,6)$ antikolinerjikler $(\% 1,7)$, parasetamol $(\% 1,7)$, kardiyovasküler sistem ilaçları $(\% 1,7)$, sindirim sistemi ilaçlarıydı (\%1,7) (Tablo 1).

İlaçlar yaz mevsimi haricindeki mevsimlerde en sık zehirlenme etkeni idi. Tarım ilaçları (organofosfat ve diğer insektisit-pestisitler) yaz mevsiminde daha sı (\%15), yakı$\mathrm{cl} /$ korozif ve iritan temizlik ürünleri aynı şekilde yaz mevsiminde (\%44), karbonmonoksit zehirlenmesi daha çok kış ve ilkbaharda görüldü. Hidrokarbon zehirlenmelerinin daha çok ilkbahar ve sonbaharda, mantar zehirlenmelerinin sonbaharda görüldüğü tespit edildi.

Tüm yaş guruplarında en sık zehirlenme etkeni ilaçlardı. Daha sonraki zehirlenme nedenleri 7 ay-4 yaş, 5-8 yaş, 13-17 yaş guruplarında sırasıyla yakıcı/koroziv ve iritan özellikli temizlik maddeleri ve 9-12 yaş grubunda ise karbonmonoksit zehirlenmeleriydi.

Zehirlenmelerin tümü akut zehirlenme olgusu olup başvuru sırasında saptanan belirti ve bulgular sıklık sırasına göre; bulantı-kusma $(\% 14,1)$, uykuya meyil $(\% 13,3)$, ağız ve orofarenkste hiperemi (\%9), bilinç kapalılı̆ı $(\% 8,5)$, ağız ve orofarenkste yanık $(\% 6,8)$, taşikardi $(\% 5,1)$ ve ajitasyon-huzursuzluk $(\% 4,7)$ idi. Hastaların 107'si $(\% 45,9)$ başvuru sırasında belirti vermiyordu.

Zehirlenmelerin 122'si $(\% 52,3)$ Çocuk Acil Polikliniği'mize gelmeden önce başka bir sağlık kuruluşuna uğramış ve bunlardan 62'sinde $(\% 26,6)$ mide yıkanmış ve aktif kömür verilmişti. Yedisinde $(\% 3,0)$ mide yıkanmış, birinde atropin ile beraber pralidoksim, birinde atropin, birinde deksametazon ile antihistaminik (feniramin maleat), birine deksametazon ile antiemetik (metoklopropamid) uygulanmıştı.

Çocuk Acil Polikliniği'mize başvuran 233 hastanın 182 'sine $(\% 78,1)$ sadece semptomatik tedavi verilmiş, 32 olguda $(\% 13,7)$ mide yıkanmış ve aktif kömür verilmişti. Üç olguda $(\% 1,2)$ aktif kömür verilmişti, bir olguda $(\% 0,4)$ mide yıkanmış, 15 'inde ise $(\% 6,4)$ oksijen tedavisi uygulanmıştı.

Acil serviste müdahale sonrası 138 olgunun $(\% 59,2)$ Çocuk Servisi veya Çocuk Yoğun Bakıma, 45 olgunun $(\% 19,3)$ Çocuk Cerrahi Kliniğine olmak üzere toplam 183'üne $(\% 78,5)$ yatış yapılmıştı. Otuz yedisi $(\% 15,9)$ ayaktan poliklinik takibi önerilerek taburcu edilmiş, 11 'i $(\% 4,7)$ yer sıkıntısı gibi çeşitli nedenlerle başka merkezlere sevk edilmişti. İkisinin $(\% 0,9)$ ise hastaneyi terk ettiği tespit etmişti.

Yakıcı/koroziv madde içen $59(\% 25,3)$ hastanın $45^{\prime}$ inin $(\% 19,3)$ bulgusu olup Çocuk Cerrahi Kliniği'nce yatışı yapılarak takibe alındı. Kırk birinde $(\% 17,5)$ ağız içi ve orofarenkste hiperemi, 20 'sinde $(\% 8,5)$ ise ek olarak ülserasyon ve yanık izi mevcuttu. Özofagoskopi yapılan altı hastadan birinde $(\% 0,4)$ özofagus mukozasında hiperemi ve ödem, birinde $(\% 0,4)$ koroziv özofajit, ikisinde $(\% 0,8)$ fibrinli ağır yanık saptandı, diğer iki hastada $(\% 0,8)$ özofagus doğal olarak değerlendirildi.

Kliniğe yatışı yapılan hastaların serviste yatış sürelerine bakıldığında en kısa sekiz saat ile en uzun 10 gün arasında değiştiği görüldü (ortalama: $43,8 \pm 29$ saat).

Çocuk Servisi veya Çocuk Yoğun Bakım Servisi'ne yatışı yapılan 139 olgudan 44'ünün $(\% 31,6)$ sadece genel destek 
Tablo 2. Zehirlenme nedeni olan etken maddeler

\begin{tabular}{|c|c|c|c|c|}
\hline Amitriptilin (trisiklik antidepresan) & 15 & 15 & 30 & $\% 12,9$ \\
\hline Demir içeren ilaçlar & 3 & 4 & 7 & $\% 3,0$ \\
\hline Antipsikotikler & 2 & 4 & 6 & $\% 2,6$ \\
\hline Antikolinerjikler & 1 & 3 & 4 & $\% 1,7$ \\
\hline Kardiyovasküler sistem ilaçları & 2 & 2 & 4 & $\% 1,7$ \\
\hline Sindirim sistemi ilaçları & 2 & 2 & 4 & $\% 1,7$ \\
\hline Dopaminerjik ajanlar & 1 & 2 & 3 & $\% 1,3$ \\
\hline Hipnotik, sedatif ve anksiyolitikler & 1 & 1 & 2 & $\% 0,9$ \\
\hline Antiseptikler/ lokal anestezikler & 0 & 2 & 2 & $\% 0,9$ \\
\hline Vitaminler, mineraller, elektrolitler & 0 & 2 & 2 & $\% 0,9$ \\
\hline İbuprofen & 0 & 1 & 1 & $\% 0,4$ \\
\hline Nonsteroid antienflamatuar ilaçlar & 1 & 0 & 1 & $\% 0,4$ \\
\hline Antiemetik & 0 & 1 & 1 & $\% 0,4$ \\
\hline Bronkodilatatörler & 0 & 1 & 1 & $\% 0,4$ \\
\hline Kas gevşeticiler & 0 & 1 & 1 & $\% 0,4$ \\
\hline Oral anti diyabetikler & 1 & 0 & 1 & $\% 0,4$ \\
\hline Çoklu ilaç alımı & 5 & 6 & 11 & $\% 4,7$ \\
\hline Farmakolojik olmayan ajanlarla zehirlenmeler & 47 & 81 & 128 & $\% 54,9$ \\
\hline Yakıcı/korozif maddeler & 21 & 38 & 59 & $\% 25,3$ \\
\hline Karbonmonoksit & 8 & 6 & 14 & $\% 6$ \\
\hline Hidrokarbonlar & 1 & 11 & 12 & $\% 5,2$ \\
\hline Tütün ürünü (Maraş otu) & 0 & 1 & 1 & $\% 0,4$ \\
\hline Yapıştırıcı & 0 & 1 & 1 & $\% 0,4$ \\
\hline Etkeni bilinmeyen olgular & 4 & 5 & 9 & $\% 3,9$ \\
\hline Toplam & 92 & 141 & 233 & $\% 100$ \\
\hline
\end{tabular}

Tablo 3. Zehirlenme etkenlerinin yaş gruplarına göre dağılımı

Zehirlenme nedeni olan etken madde grupları

Farmakolojik ajanlar Yakıcı/korozif, iritanlar

Tarım ilaçları

Karbonmonoksit

Hidrokarbonlar

Mantar

Bitkisel ürünler

Etkeni bilinmeyenler

Fare zehiri

Diğerleri

Toplam

\begin{tabular}{|c|c|}
\hline \multicolumn{2}{|c|}{} \\
\hline $\mathbf{2}$ 7 ay-4 yaş \\
\hline $\mathbf{n}$ & $\%$ \\
\hline 73 & 42,4 \\
\hline 51 & 29,7 \\
\hline 14 & 8,1 \\
\hline 7 & 4,1 \\
\hline 9 & 5,2 \\
\hline 2 & 1,2 \\
\hline 2 & 1,2 \\
\hline 6 & 3,5 \\
\hline 6 & 3,5 \\
\hline 2 & 1,2 \\
\hline 172 & 100,0 \\
\hline
\end{tabular}

Yaş Grupları

\begin{tabular}{c|c|c|c|c|c|c|c|}
\multicolumn{2}{c|}{$\mathbf{5 - 8}$ yaş } & \multicolumn{2}{c|}{9} & \multicolumn{2}{c|}{$\mathbf{1 3 - 1 7}$ yaş } & \multicolumn{2}{c|}{ Toplam } \\
$n$ & $\%$ & $\mathbf{n}$ & $\%$ & $\mathbf{n}$ & $\%$ & $\mathbf{n}$ & $\%$ \\
\hline 10 & 34,5 & 9 & 40,9 & 4 & 40,0 & 96 & 41,2 \\
\hline 6 & 20,7 & 4 & 18,2 & 3 & 30,0 & 64 & 27,5 \\
\hline 3 & 10,3 & 0 & 0,0 & 0 & 0,0 & 17 & 7,3 \\
\hline 2 & 6,9 & 5 & 22,7 & 0 & 0,0 & 14 & 6,0 \\
\hline 3 & 10,3 & 0 & 0,0 & 0 & 0,0 & 12 & 5,2 \\
\hline 0 & 0,0 & 3 & 13,6 & 1 & 10,0 & 6 & 2,6 \\
\hline 2 & 6,9 & 0 & 0,0 & 2 & 20,0 & 6 & 2,6 \\
\hline 3 & 10,3 & 1 & 4,5 & 0 & 0,0 & 10 & 4,3 \\
\hline 0 & 0,0 & 0 & 0,0 & 0 & 0,0 & 6 & 2,6 \\
\hline 0 & 0,0 & 0 & 0,0 & 0 & 0,0 & 2 & 0,9 \\
\hline 29 & 100,0 & 22 & 100,0 & 10 & 100,0 & 233 & 100,0 \\
\hline
\end{tabular}


tedavisi ile izlendiği, 89'una $(\% 63,3)$ "forse diürez", dördüne $(\% 3,3)$ "forse diürez"le birlikte alkalizasyon, 14'üne $(\% 10,1)$ mide yıkaması ve aktif kömür, üçüne $(\% 2,2)$ sadece aktif kömür uygulandığı görüldü.

İlk başvurulan merkez de dahil olmak üzere Çocuk Acil Servisi'mizde ve yatış sonrası serviste toplam 233 hastaya uygulanan tedavilere genel olarak bakıldığında; $\% 48,5$ 'inde sadece gözlem ve genel destek tedavisi, \%22,7'sine mide yıkaması, aktif kömür ve "forse diürez", \%11,6'sına mide yıkaması ve aktif kömür, \%11,2'sine "forse diürez", \%3,0'üne özgül antidot, \%2,6'sına çoklu doz aktif kömür ve "forse diürez", \%1,7'sine alkalizasyon ve "forse diürez", \%2,6'sına sadece aktif kömür, \%2,6'sına mekanik ventilatör dahil ileri yaşam desteği uygulanmıştı.

\begin{tabular}{|c|c|c|}
\hline Belirti ve Bulgular & Toplam* & $\%$ \\
\hline Belirti ve bulgu yok & 107 & $\% 45,9$ \\
\hline Bulantı-kusma & 33 & $\% 14,1$ \\
\hline Konfüzyon/ Uykuya meyil & 31 & $\% 13,3$ \\
\hline Ağız içi ve orofarenkste hiperemi & 21 & $\% 9,0$ \\
\hline Şuur kaybı/ şuur kapalı olması & 20 & $\% 8,5$ \\
\hline Ağız içi ve orofarenkste ülserasyon ve yanık izi & 16 & $\% 6,8$ \\
\hline Taşikardi & 12 & $\% 5,1$ \\
\hline Ajitasyon/ huzursuzluk & 11 & $\% 4,7$ \\
\hline Takipneik solunum & 8 & $\% 3,4$ \\
\hline Hipersalivasyon/ ağız içinde salgı artışı & 7 & $\% 3,0$ \\
\hline Karın ağrısı/ karında duyarlııı & 7 & $\% 3,0$ \\
\hline Konvülziyon & 7 & $\% 3,0$ \\
\hline Nefes darlığı/ solunum sıkıntısı & 5 & $\% 2,1$ \\
\hline Ciltte hiperemi & 4 & $\% 1,7$ \\
\hline Miyozis (pupillerde daralma) & 4 & $\% 1,7$ \\
\hline Midriyazis (pupillerde genişleme) & 3 & $\% 1,2$ \\
\hline Hirıltilı solunum & 2 & $\% 0,9$ \\
\hline Solunum yetersizliği & 2 & $\% 0,9$ \\
\hline Hipertansiyon & 2 & $\% 0,9$ \\
\hline Hipotansiyon & 2 & $\% 0,9$ \\
\hline Ağız kuruluğu & 2 & $\% 0,9$ \\
\hline Spastisite & 2 & $\% 0,9$ \\
\hline Ense sertliği & 2 & $\% 0,9$ \\
\hline Baş ağrısı & 2 & $\% 0,9$ \\
\hline Özofagusta ülsere (II-III. derece) yanık & 1 & $\% 0,4$ \\
\hline Koma & 1 & $\% 0,4$ \\
\hline Koreatetoik hareketler & 1 & $\% 0,4$ \\
\hline Babinski pozitifliği & 1 & $\% 0,4$ \\
\hline Ağızda/ nefeste değişik koku & 1 & $\% 0,4$ \\
\hline Ciltte terleme artışı & 1 & $\% 0,4$ \\
\hline Hipertermi & 1 & $\% 0,4$ \\
\hline Hipotermi & 1 & $\% 0,4$ \\
\hline Hepatomegali & 1 & $\% 0,4$ \\
\hline Göz takibi azalması & 1 & $\% 0,4$ \\
\hline Nistagmus & 1 & $\% 0,4$ \\
\hline Siyanoz & 1 & $\% 0,4$ \\
\hline Tremor & 1 & $\% 0,4$ \\
\hline Toplam & 326 & $\% 100$ \\
\hline
\end{tabular}

* Aynı hastada birden fazla belirti görülebildiğinden belirti ve bulgular toplamı olgu toplamından fazla görülmektedir.
Tarım ilacı ile zehirlenmiş olan iki hasta ve selektif serotonin "re-uptake" inhibitörü ile zehirlenen bir hasta olmak üzere toplam üç hastaya $(\% 1,2)$ bilinç kaybı, solunum ve dolaşım yetersizliği gelişmesi nedeniyle entübasyon ve mekanik ventilasyon desteği verilmişti. Ciddi selektif serotonin "re-uptake" inhibitörü zehirlenmesi olan bu hasta yatışının ikinci gününde ventriküler fibrilasyon ve hipotansiyon nedeniyle eksitus $(\% 0,4)$ olmuştu.

\section{Tartışma}

Çocuk acil polikliniğimize başvuran hastaların \%1,14'ünü akut zehirlenmeler oluşturmaktaydı. Yurt dışında farklı ülkelerde yapılan çalışmalarda zehirlenmelerin acil başvurularına oranları; Nijerya'da \%0,52, İspanya'da \%0,3-0,4, Hindistan'da $\% 0,23-3,3$, Güney Kıbrıs'ta \%3, Bangladeş'te $\% 4,7$ olarak bildirilmektedir (7-10). Ülkemizde; Ankara'da \%0,36, Denizli'de $\% 1,2$, Şanlıurfa'da \%1,1, Eskişehir'de \%1,8, İstanbul'da $\% 1,16$, Kayseri'de \%6,2 olduğu bildirilmiştir (2,4,11-15). Türkiye genelinde zehirlenme olgularının tüm acil olgulara oranının ise $\% 0,9$ olduğu bulunmuştur (15). Bu oranın ülkemizde daha düşük olmasının nedeni, zehirlenmelerin az olması değil, acil servislerde gerçek acil hastaların yanında diğer hastalara da hizmet verilmesi olabilir.

Çalışmamızda zehirlenmelerin \%72,1'i 1-4 yaş gurubundaydı. Amerika Birleşik Devletleri'nde 2007 yılı verilerine göre 2482041 zehirlenmenin \%51,23'ünün beş yaşından küçük çocuklar olduğu bildirilmiştir (16). Hindistan Kashmir bölgesinde 1997-2000 yıllarını kapsayan çalışmada (17) \%48,9'u 1-5 yaş grubunda, Yunanistan'da yapılan bir çalışmada (18) \%93'ünün beş yaşın altında olduğu bildirilmiştir. Hemen tüm çalışmalarda zehirlenmelerin en sık 1-5 yaşları arasında görüldügü bildirilmektedir. Zehirlenmelerin beş yaş öncesinde daha sık görülme nedeni bu yaştaki çocukların bilinç seviyelerinin düşük olmasıdır $(2,19)$. Bu bulgumuz Türkiye'deki ve diğer ülkelerdeki çalışmalarla benzerlik göstermektedir $(2,5,11,15-19)$.

Tablo 5. Akut zehirlenme olgularımızda uygulanmış olan tedavi yöntemleri

\begin{tabular}{|l|c|c|}
\hline Uygulanan tedavi & $\mathbf{n}^{*}$ & $\%$ \\
\hline Genel destek tedavisi ve takip & 113 & $\% 48,5$ \\
\hline "Forse diürez" & 85 & $\% 36,5$ \\
\hline Aktif kömür uygulaması & 83 & $\% 35,6$ \\
\hline Mide yıkanması & 80 & $\% 34,4$ \\
\hline Oksijen tedavisi & 15 & $\% 6,4$ \\
\hline Antidot uygulaması & 7 & $\% 3,0$ \\
\hline Çoklu doz aktif kömür & 6 & $\% 2,6$ \\
\hline Alkalizasyon & 4 & $\% 1,7$ \\
\hline Mekanik ventilasyon & 3 & $\% 1,3$ \\
\hline Antidot (toplam) & 7 & $\% 1,3$ \\
\hline N-asetilsistein & 3 & $\% 1,3$ \\
\hline Pralidoksim ve atropin & 3 & $\% 0,4$ \\
\hline Atropin & 1 & $\% 100$ \\
\hline Toplam & 396 & $\%$ \\
\hline
\end{tabular}

* Olguların birçoğunda birden fazla tedavi yöntemi uygulandığından toplamı olgu toplamından fazla görülmektedir. 
Çalışmamızda zehirlenmelerin en az olduğu $(\% 4,3)$ yaş grubu 13-17 yaş grubu idi. Birçok çalışmada 12-17 yaş grubunda zehirlenme sıklığında ikinci bir artış görülmüştür. Kırel ve ark. (13) zehirlenmelerin \%29,1'inin 15-18 yaş grubunda, Öntürk ve ark. (14) \%24,1'inin 12-17 yaş grubunda, Aygün ve ark (20) ise \%21,4'ünün 12-16 yaş grubunda olduğunu bildirmektedir. Kahramanmaraş'ta 13-17 yaş gurubundaki intihar olaylarının ve zehirlenme oranlarının Türkiye genelinden düşük olduğu dikkat çekmektedir. Bunun nedeni bölgemizdeki insanların sosyokültürel yönden yaşantılarının mütevazi ve aile bağlarının kuvvetli olması olabilir.

Çalışmamızda zehirlenmelerin \%60,5’i erkek çocuklardı. Ülkemizde başka şehirlerde yapılan çalışmalarda da benzer sonuçlar bulunmuştur (12,14,15,20-22). Bu durum erkek çocukların daha serbest, ev içi ve dışında ebeveynlerden bağımsız daha fazla zaman geçirmeleri ile ilgili olabilir.

Çalışmamızda zehirlenmeler cinsiyet olarak sadece 13-17 yaş grubunda kızlarda daha sık idi. Bu yaş grubundaki kızlardaki zehirlenmeler daha çok intihar amaçıı ilaç alımı ile ilgilidir ve kızların daha duygusal olmaları, daha çok baskı hissetmeleri ve ergenlik döneminde ruhsal çatışmaları daha çok yaşamaları ile ilgilidir. Ülkemizde yapılmış olan diğer çalışmalarda da benzer sonuçlara ulaşılmıştır $(2,14,23)$.

Zehirlenmelerin en çok 12:00-18:00 saatleri arasında olduğunu, hastane başvurularının ise en çok 18:00-22:00 saatleri arasında olduğunu gördük. Özdemir ve ark (6) da zehirlenmenin en çok olduğu saatleri ve hastane başvuru saatlerini benzer şekilde bulmuşlardır. 12:00-18:00 saatleri arası babanın evde olmaması, annenin yemek hazırlama telaşında olması, çocukların da gün boyu aktivite sonrası acıkıp susaması gibi nedenlerle bu saatlerde zehirlenme sıklığı artmaktadır. Dolayısıyla hastane başvuruları babanın eve gelmesinin beklenmesi ve en yakın devlet hastanesinde ilk müdahalelerin yapılmasına kadar geçen sürenin ardından hastanemize 18:00-22:00 saatleri arasında başvurulmasına neden olmaktadır.

Çalışmamızda zehirlenmelerin \%97'sinin kaza sonucu, ancak ergenlik dönemdeki kızlarda ise daha çok intihar amacıyla meydana geldiğini gördük. Ülkemizde yapılan diğer çalışmalarda da benzer sonuçlar bulunmuştur $(14,22-24,25)$. Kızlarda intihar girişiminin fazla olmasının nedeni kızların daha duygusal olmaları olabilir.

Çalışmamızda en sık zehirlenme etkeni her yaş grubunda ilaçlardı $(\% 41,2)$ ve ilaçlardan da antidepresanlar ilk sırada yer almaktaydı $(\% 14,0)$. Ülkemizde çocukluk çağında zehirlenmelerin en sık ilaç alımı ile olduğu, diğer nedenlerin sıklı̆ının bölgelerin özelliklerine göre değiştiği daha önceki çalışmalarda da bildirilmiştir (15,20,22,24,26-29). Uçar ve ark. (23) 1993 yılında, Kalyoncu ve ark. (30) ise 1996 yılında Trabzon'da yaptıkları iki ayrı çalışmada da antidepresanlar zehirlenme etkeni olan farmakolojik ajanlar arasında ilk sırada yer almıştır. Son yıllarda yapılan çalışmalarda antidepresanlar ile zehirlenme sıklığında artı̧ olduğu dikkat çekmektedir.

Yakıcı-koroziv maddelerin farmakolojik ajanlardan sonraki en sık $(\% 25,3)$ zehirlenme nedeni olduğu görüldü. Yurtdışındaki çalışmalarda endüstriyel toplumlarda kişisel bakım ürünleri, kozmetikler, temizlik maddeleri, bahçe malze- meleri ve ilaçlar ilk sıralarda yer alırken, gelişmekte olan ve ekonomisi tarıma dayalı ülkelerde özellikle organik fosforlu insektisit ve pestisitler, besin ve bitki zehirlenmeleri zehirlenme etkenleri arasında ilk sıralarda gelmektedir (31-35). Deniz ve ark.larının (36) 2009'da Kırıkkale'de yaptığı çalışmada koroziv maddeler zehirlenme etkeni olarak ikinci sık etken olarak bildirilmiştir. Kahramanmaraş'ta temizlik maddelerinin açık-markasız ve genellikle su ya da meşrubat şişelerine doldurularak pazarlanması, evlerde banyo ve mutfaklarda açıkta bırakılması bunun nedeni olabilir. Yakıcı-koroziv maddeler için emniyetli kapakların kullanılması çocukların bu maddelerle zehirlenmesinin önünü alabilir.

Olgularımızda bulantı-kusma, dalgınlık, ağız mukozasında hiperemi, şuur kaybı, taşikardi, huzursuzluk ve takipne en sık rastlanan belirtilerdi. Bu sonuçlar daha önceki yayınlar ile benzerlik göstermektedir $(4,20,23,25,27-29)$.

Hastalarımızın hastanede yatış süreleri 8 saat-10 gün arasında (ortalama: 44 saat) değişmekteydi. Aji ve ark. (15) çalışmasında ortalama yatış süresi 12 saat, Andıran ve ark. (26) çalışmasında 3,2 gün, Tunç ve ark. (27) çalışmasında ise 1,6 gün olarak bildirilmiştir. Hastanedeki ortalama yatış sürelerimiz ülkemizdeki ortalamalar ile benzerdir.

Çalışmamızda zehirlenme olgularındaki ölüm oranı $\% 0,4$ bulundu. Amerika Birleşik Devletleri'nde 1992 yılında zehir kontrol merkezlerinin işbirliğiyle yapılan bir çalışmada zehirlenme olgularında ölüm oranının \%0,036 olduğu bildirilmiştir (37). Gelişmekte olan ülkelerde \%1,8 ile \% 11,6 arasında değişen yüksek ölüm oranları bildirilmektedir $(7,10,33,34)$. Ülkemizde zehirlenme olgularında ölüm oranını Erzurum'da Ertekin ve ark. (5) $\% 5,5$, Orbak ve ark. (22) \%2,2, Sivas'ta Ergür ve ark. (28) \%2,05, Elazığ'da Aygün ve ark. (20) \%2, Samsun'da Totan ve ark. (29) $\% 1,2$, Eskişehir'de Öntürk ve ark. (14) \%0,6 olarak bildirmiştir. Kondolat ve ark. (4) 2006-2007 yıllarında Kayseri'de yaptıkları 491 olguyu içeren çalışmada hiç ölüm olmadığı bildirilmiştir. Eskişehir'de Kırel ve ark. (13) 1988'de yaptıkları çalışmada zehirlenme olgularında ölüm oranını \%2,8 olarak bildirirken, aynı hastanede Öntürk ve ark. (14) Ocak 1999-Aralık 2001 arasında yaptıkları çalışmada \%0,6 olarak bildirilmiştir. Yine benzer şekilde Hıncal ve ark. (24) 1975-1984 yılları arasında Ankara'da Hacettepe Üniversitesine başvuran zehirlenme olgularında ölüm oranını \%4,9 olarak bildirirken, aynı hastanede 1995-2000 yılları arasında yapılan çalışmada da \%0,4'ük oldukça düşük bir ölüm oranı saptanmışıı (30). Son yıllarda ülkemizde yapılan birçok çalışmada ölüm oranlarının giderek azaldığı görülmektedir. Bunun nedeni ulaşımdaki, tanı ve tedavideki gelişmeler olabilir.

Bir çocuğun bakımından sorumlu olan kişinin o çocuğun fiziki güvenliğini, meydana gelecek zararlardan korunmasını, temel intiyaçlarını karşılama, eğitimi ve tıbbi bakımını sağlama zorunluluğu vardır (38). Bu nedenle çocuk zehirlenmelerinde çocuğun bakımından sorumlu olan kişi ve diğer kişilerin sorumluluğu da unutulmamalı, adli vaka bildiriminin yapılarak adli süreç başlatılmalıdır.

Sonuç olarak çalışmamızda en sık zehirlenme etkeni ilaçlardır ve bunu ikinci sırada yakıcı-koroziv maddeler takip etmektedir. Emniyetli kapaklar ve eğitim çocukluk çağı akut zehirlenmelerini azaltabilir. 


\section{Çıkar çatışması: Bildirilmedi.}

\section{Kaynaklar}

1. Sarıkayalar F. Çocukluk çağında zehirlenme. Katkı Ped Derg 1990; 11: 201-14.

2. Aji DY, İlter O. Türkiye'de çocuk zehirlenmeleri. Türk Ped Arş 1998; $33: 154-8$.

3. Müftü Y. Çocukluk çağı kazaları. Çocuk Sağ ve Hast Derg 1975; 18 : 78-90.

4. Kondolot M, Akyıldız B, Görözen F, ve ark. Çocuk acil servisine getirilen zehirlenme olgularının değerlendirilmesi. Çocuk Sağ ve Hast Derg 2009; 52: 68-74.

5. Ertekin V, Altınkaynak S, Alp H, Yiğit H. Çocukluk çağında zehirlenmeler. Son üç yıldaki vakaların değerlendirilmesi. Çocuk Derg 2001 1: 104-9.

6. Özdemir R, Bayrakcı B. Zehirlenmeler ve Hacettepe Deneyimi. Katkı Ped Derg 2009; 31: 47-87

7. Dutta AK, Seth A, Goyal PK, et al. Poisoning in children: Indian scenario. Indian J Ped 1998 65: 365-70.

8. Koliou M, loannou C, Andreou K, et al. The epidemiology of childhood poisonings in Cyprus. Eur J Ped 2009; 17: 1124-8.

9. Rashid MM, Hasan MA, Chowdhury FR. Childhood acute poisoning in a tertiary medical college hospital of Bangladesh. Mymensingh Med J 2007; 16: $12-4$.

10. Adejuyigbe EA, Onayade AA, Senbanjo IO, et al. Childhood poisoning at the Obafemi Awolowo University Teaching Hospital. Niger $J$ of Med 2002; 11: 183-6.

11. Bostancı İ, Küpelioğlu M, Bedir E, ve ark. Çocuk zehirlenme olgularının retrospektif değerlendirilmesi. Tur Klin Ped 1999; 8: 143-6.

12. Kösecik M, Arslan SO, Çelik IL, ve ark. Şanlıurfa'da çocukluk çağı zehirlenmeleri. Çocuk Sağ ve Hast Derg 2001; 44: 20-53.

13. Kırel B, Ünlüoğlu i, Doğruel N, et al. Eskişehir bölgesinde çocukluk çağı zehirlenmelerin retrospektif analizi. Tur Klin Ped 2000; 9: 158-63.

14. Öntürk Y, Uçar B. Eskişehir bölgesinde çocukluk çağı zehirlenmelerinin retrospektif değerlendirilmesi. Çocuk Sağ Hast Derg 2003; 46: 103-13.

15. Aji DY, Keskin S, IItter Ö. i..Ü. Cerrahpaşa Tıp Fakültesi Çocuk Sağlığı ve Hastalıkları Anabilim Dalı Acil Biriminde izlenen zehirlenmelerin değerlendirilmesi. Tur Ped Arș 1998; 148-53.

16. Bronstein AC, Spyker DA, Louis R, et al. 2007 Annual Report of The American Association of Poison Control Centers National Poison Data System (NPDS): 25th Annual Report. Clinical Toxicology 2008; 46: 927-1057.

17. Wani KA, Ahmad M. Poisoning in children. JK - Practitioner 2004; 11: 274-5.

18. Petridou E, Kouri N, Polychronopoulou A, et al. Risk factors for childhood poisoning: a case control study in Greece. Injury Prevention 1996; 2: 208-11.
19. Kayaalp O. Akut zehirlenme tedavisinde genel ilkeler. Tıbbi Farmakoloji. Cilt 1. Ankara: Garanti Basımevi, 1978: 244-385.

20. Aygün $A D$, Güvenç $H$, Türkbay $D$, et al. Hastanemizde izlenen zehirlenme olgularının değerlendirilmesi. Nobel Med Klin Bil 1995; 3: 48-51.

21. Özdoğan H, Davutoğlu $M$, Boşnak $M$, et al. Pediatric poisonings in southeast of Turkey: epidemiological and clinical aspects. Hum \& Exp Toxic 2008; 27: 45-8

22. Orbak Z, Selimoğlu MA, Alp H. Erzurum Bölgesinde çocuklarda zehirlenme vakalarının değerlendirilmesi. Çocuk Sağ ve Hast Derg 1996; 39: 497-504.

23. Uçar B, Ökten A, Mocan H. Karadeniz bölgesinde çocuk zehirlenme vakalarının retrospektif incelenmesi. Çocuk Sağ ve Hast Derg 1993; 36: 363-71.

24. Hıncal F, Hıncal AA, Müftü Y, et al. Epidemiological aspects of childhood poisonings in Ankara: A 10-year survey. Human toxicology 1987; 6: 147-52.

25. Çuhadaroğlu F, Sonuvar B. Adolesan intiharları ve kendilik imgesi. Türk Psik Derg 1993; 4: 29-38.

26. Andıran N, Sarıkayalar F. İhsan Doğramacı Çocuk Hastanesinde altı yılda izlenen akut zehirlenmeler. Katkı Ped Derg 2001; 22: 396-408.

27. Tunç B, Örmeci AR, Dolgun A, Karaca H. Isparta Bölgesinde çocukluk çağı zehirlenme nedenleri. Çocuk Sağ ve Hast Derg 1995; 38: 211-8.

28. Ergür AT, Sütçü I, Tanzer F. Pediatri servisimizdeki zehirlenme olgularının değerlendirilmesi: 1990-1998. Tur Klin Ped 1999; 8: 9-14.

29. Totan M, Sancak R, Küçüködük Ş. Ondokuz Mayıs Üniversitesi Tıp Fakültesi Çocuk Acil Servisi'ne başvuran intoksikasyon hastalarının değerlendirilmesi. Tur Klin Ped 1999; 8: 126-9.

30. Kalyoncu MD, Ökten A, Kalyoncu Ni, ve ark. Doğu Karadeniz Bölgesinde çocukluk çağında pestisitlerle zehirlenme vakalarında artış. Çocuk Sağ ve Hast Derg 1996; 39: 505-10.

31. Perry HE. Pediatric poisonings from household products; hydrofluoric acid and methacrylic acid. Current Opinion in Ped 2001; 13: 157-61.

32. Belson MG, Simon HK. Utility of comprehensive toxicologic screens in children. The Am J of Emerg Med 1999; 17: 221-4.

33. Fernando R, Fernando DN. Childhood poisoning in Sri Lanka. Indian $\mathrm{J}$ of Ped 1997; 64: 457-60.

34. Buch NA, Ahmed K, Sethi AS. Poisoning in children. Indian J of Ped 1991; 28: 521-4.

35. Khare $\mathrm{M}$, Bhide $\mathrm{M}$, Ranade $\mathrm{A}$, et al. Poisoning in children - analyses of 250 cases. J Postgrad Med 1990; 89: 203-8.

36. Deniz T, Kandiş H, Saygun M, ve ark. Kırıkkale Üniversitesi Tıp Fakültesi Acil Servisine başvuran zehirlenme olgularının analizi. Düzce Tıp Fak Derg 2009; 11: 15-20.

37. Litovitz T, Manoguerra A. Comparison of pediatric poisoning hazards: as analysis of 3.8 million exposure incidents. Pediatrics 1992; 89: 999-1006.

38. Gürpınar T, Aşırdizer M. Zehirlenmelerde hekim sorumluluğu. Turk Klin Cer Tıp Bil Der 2006; 2: 56-62. 